\title{
Een goede medische opleiding houdt rekening met de geloofsovertuiging en cultuuropvattingen van studenten*
}

\author{
P.G.P. Herfs
}

Bij de inrichting van de onderwijsleersituatie dient rekening gehouden te worden met relevante kenmerken van de studentenpopulatie. ${ }^{1}$ Dat zijn onder meer: vooropleiding, sekse, leeftijd, etniciteit, culturele achtergrond en geloofsovertuiging. Volgens het Raamplan 2001 Artsopleiding moet de arts in opleiding beschikken over kennis en inzicht met betrekking tot "menselijk gedrag in verschillende omstandigheden met name in probleemsituaties en bij verschillende culturele achtergronden" (www.vsnu.nl/web/show/id=46742/langid= 43). De opleiding en de doelstellingen zijn voor iedereen hetzelfde: er wordt niet toegewerkt naar een situatie waarin bijvoorbeeld Marokkaanse artsen exclusief werken voor Marokkaanse patiënten. De medische zorg in Nederland is voor iedereen toegankelijk, hetgeen haaks staat op de organisatie van de volksgezondheid langs etnische lijnen.

Toch dient men in de medische opleiding rekening te houden met de geloofsopvatting van studenten. Het oefenen van lichamelijk onderzoek op medestudenten kan voor bijvoorbeeld moslima's problematisch zijn. Van opleiders mag verwacht worden dat zij met "gewetensbezwaren" van studenten prudent omgaan. Dan worden problemen niet gebagatelliseerd of genegeerd, maar wordt gezocht naar alternatieven: moslima's kunnen in ieder geval vrouwelijk lichamelijk onderzoek op elkaar verrichten.
Wereldwijd wordt verschillend en cultuurbepaald omgegaan met het onderzoek van mammae en het inwendig onderzoek van vrouwelijke patiënten door mannelijke artsen. ${ }^{2}$ In sommige landen wordt een patiënte altijd vergezeld door een chaperonne, met wie ook de band kan verschillen: in islamitische landen is het een familielid, in het Verenigd Koninkrijk eerder een verpleegkundige. De Britse General Medical Council schrijft dat "een chaperonne aan iedere patiënt moet worden aangeboden die een "intiem onderzoek" moet ondergaan, bijvoorbeeld van de borsten, de genitalia of het rectum" (www.gmc-uk.org/guidance/library/intimate_examinations.asp). Bij de huidige vervaging van lands- en cultuurgrenzen dienen wij in onze opleiding hier rekening mee te houden. Een goede balans met de eisen die in Nederland aan de artsopleiding worden gesteld ten aanzien van de training in het lichamelijk onderzoek van mannelijke en vrouwelijke patiënten, is noodzakelijk.

Deze flexibiliteit mag ook aan van oorsprong buitenlandse studenten worden gevraagd. Dat geldt bijvoorbeeld voor wel of geen alcoholgebruik bij een bijeenkomst van een coassistentengroep op vrijdagvond of moskeebezoek op momenten dat onderwijs gegeven wordt. ${ }^{3}$ Het bespreekbaar maken van dit soort dilemma's en een constructieve opstelling van alle belanghebbenden moeten leiden tot een goede oplossing.

\footnotetext{
* Dit artikel verschijnt ook in het Nederlands Tijdschrift voor Geneeskunde.
} 
Een medische opleiding kan ook gebruikmaken van de culturele verscheidenheid binnen de studentenpopulatie. In de Utrechtse geneeskundeopleiding geven buitenlandse artsen en studenten voorlichting aan jongerejaars over de organisatie van de gezondheidszorg in de herkomstlanden, zoals Afghanistan, Irak en Rusland, de beschikbaarheid van medische apparatuur en medicijnen, de verhouding arts-patiënt en de afstanden die patiënten moeten overbruggen om een arts te zien. Zo wordt autochtone studenten de ogen geopend, terwijl het de buitenlandse artsen in staat stelt uitleg te geven over de organisatie van de volksgezondheid in hun land van herkomst.

De medische opleiding kan niet zonder aandacht voor de geloofsovertuigingen en cultuuropvattingen van studenten.

\section{Literatuur}

1. Corte E de, Geerligs CT, Lagerweij NAJ, Peters JJ, Vandenberghe R. Beknopte didaxologie. Groningen: Tjeenk Willink; 1976.

2. Gawande A. Naked. N Engl J Med 2005;353:6458.

3. Haalboom JRE, Herfs PGP. De inpassing van buitenlandse artsen in het Nederlands curriculum. Het Utrechtse model. Med Contact 1998;53:14157.

De auteur:

Drs. P.G.P. Herfs is onderwijskundige.

Correspondentieadres:

Drs. P.G.P. Herfs, Universiteit Utrecht, Kriekenpitplein 21-22, kamer 1.01, 3584 EC Utrecht, p.g.p.herfs@uu.nl.

Belangenconflict: geen gemeld.

Financiële ondersteuning: geen gemeld.

\section{Summary}

The ethnic composition of the student population is highly diverse, just like that of the Dutch population, and the medical curriculum should take this into consideration. The curriculum assumes that doctors will be able to recognise problems that are related to a particular cultural background. The flexibility that medical curricula are expected to display in the way they deal with cultural diversity may also be expected of both Dutch and originally non-Dutch students. Opening up dilemmas for discussion and searching for solutions in a constructive manner during the medical curriculum can contribute to a professional approach to patients later in life. (Herfs PGP. A good medical curriculum takes the religious beliefs and cultural background of the students into consideration. Dutch Journal of Medical Education 2006;25(6):296-297.) 